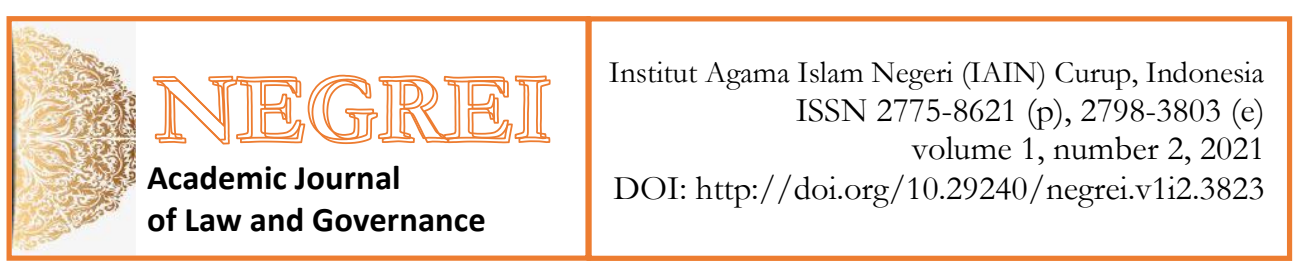

\title{
The Opposition in The Shar'i Text and The Constitution
}

\author{
Busman Edyar, Ilda Hayati, Gusti Pangestu \\ Institut Agama Islam Negeri Curup \\ busmanedyar@iaincurup.ac.id (correspondence)
}

\begin{abstract}
This paper aims to examine the opposition in the Islamic perspective (especially the study of verse/hadith texts) and in the Indonesian constitution. The type of research used is a literature study with a qualitative approach which is analyzed by means of content analysis. The results of the research are that the opposition in meaning as a counterweight, warning or as checks and balances, is justified in Islamic law. Even when this role is lost in the life of the state, the community will not only suffer losses but will also have the potential to receive punishment from Allah SWT. Meanwhile, from a constitutional perspective, the opposition is not literally written down, but the role of the House of Representatives with the function of controlling and supervising the administration of the state is at least a signal that opposition is not taboo in the Indonesian state system. Even the opposition is needed so that the state process can run well.
\end{abstract}

Keywords: opposition, Shari'a, and Constitution. 
NEGREI : Academic Journal of Law and Govenance,

Volume 1, Number 2, 2021

\section{Introduction}

Every countryman's desire is to see excellent government implemented in their country. The indications can be seen in a government that creates and implements professionalism, accountability, transparency, outstanding service, democracy, efficiency, effectiveness, and the rule of law, all of which are widely acknowledged. In another lexical sense, good governance refers to the activity of a government institution that is carried out in the interests of the people and in accordance with applicable norms in order to realize the state's ideals, in which power is exercised by the people and regulated at various levels of state government in relation to social resources, culture, politics, and the economy. Good governance, according to the United Nations Development Program (UNDP), is "the exercise of political, economic, and administrative authority to manage a nation's affairs at all levels." The term "governance" refers to the "use" or "application" of authority, lawful power, or legitimate power in political, economic, and administrative contexts to manage national affairs at all levels. The last meaning of governance, According to the State Administration Institute, has three legs: economic, political, and administrative. Economic governance refers to the process of making decisions that have a direct or indirect impact on the economic activity of the country in question, as well as those of other countries. As a result, economic governance has an impact on equity, power, and the quality of life. Political governance is the process of making lawful and authoritative decisions and implementing them in a country. Administrative governance, on the other hand, is a policy implementation mechanism that makes the public sector more efficient, effective, impartial, accountable, and transparent.

Countries that fail to establish good governance are more likely to become authoritarian and engage in power abuse. As, in principle, "power tends to corrupt, and absolute power corrupts totally," as John Emerich Edward DalbergActon put it in his letter to Bishop Mandell. This implies that power is subject to abuse in theory. This is exactly the point of view of Niccolo Machiavelli (14691527), who believes that power is everything. According to the well-known Italian politician, obtaining and maintaining it (including utilizing it) is not an issue. Moral ideals, much alone religious convictions, should not stand in the way of the Ruler (Il Principe) achieving that purpose. In order to keep power, a ruler may be ruthless, murder, not afraid to lie, corrupt, terrorize, intimidate, and many other things. 


\section{Busman Edyar, Ilda Hayati, Gusti Pangestu The Opposition in The Shar'i Text and The Constitution}

The need for opposition is at this level. He will be advocatuus diaboli, or the devil's advocate, who will play the role of a demon who constantly disturbs but also saves. In this instance, the opposition is obligated to point out a policy's flaws. Exactly like Prof. Sri Sumantri stated, if the opposition is implemented in the Republic of Indonesia, it will be tasked with correcting the government's conduct. In this sense, the opposition's mission must be integrated into the Indonesian government's daily operations. As a result, if the policy is adopted, all negative side effects will be minimized. Accountability will be given more attention by the authorities as a result of the presence of the opposition. The ruler will always explain and be accountable for why a policy is enacted, what the basis for its goal and urgency is, and how the policy is carried out.

The opposition is responsible with not only reminding the government of wrongdoings (sins of commission), but also with demonstrating what it should be doing but isn't (sin of omission). Power has a tendency to focus on itself, not merely to expand and develop it.

Furthermore, the necessity of the concept of checks and balances is at the root of the opposition. This concept was developed in the United States as a continuation of the idea of power sharing. The essence of this concept is that the branches of power must be able to control and balance each other. It is

hoped that as a result of this mutual control and balance, each branch of power will not act solely in its own self-interest. This control and balancing allows the existing parties, both in the legislature and the executive, to control each other and remind the government to stay true to the people's will. This balance within or between branches allows for the emergence of opposition to the current government. According to Amadigwe (2004), even in a parliamentary government scheme, ministers must still be accountable for their policies in front of the legislature, where the opposition will usually criticize the policies implemented.

As a result, opposition is an effective mechanism for reminding each other of what is right and for the common good. Opposition is required to openly examine political discourse in public. It would be naive to believe that the government and its advisors can formulate precisely what is urgently required in politics, law, and culture.

\section{Discussion}


NEGREI : Academic Journal of Law and Govenance,

Volume 1, Number 2, 2021

\section{The Definition and Importance of Opposition}

Opposite (opposition), means the opponent or opposing party. "The term opposition comes from the word "opponeren," which means to fight or oppose, according to Sri Sumantri. Thus, opposition refers to a negative or opposing action. On the other hand, opposition indicates that there are differences of opinion or viewpoints on one or more issues. This can happen in a variety of situations. Meanwhile, the opposition is defined as the opposing party in the representative council and so on that opposes and criticizes the ruling group's opinions or political policies, according to the Kamus Besar Bahasa Indonesia $(\mathrm{KBBI})$.

In general, opposition is often interpreted as "opposite" or "something that takes a different stance on something else." Some people interpret opposition in the political context as an informal form of disagreement or contestation among institutions holding power. Political opposition, on the other hand, is a type of contestation that is related to or guaranteed by the constitution.

Indeed, there are various definitions of opposition, but the essence that always exists in the meaning of opposition is related to a group of people who are not part of the government and have the legal right to express their opinions and carry out activities aimed at criticizing and controlling attitudes, views, or policies. Government based on an ideological viewpoint, empirical reality, or a specific interest.

The opposition's functions are as follows: first, as a balance of power, namely the existence of forces outside the government that provide alternative thoughts or attitudes and cause a balance so that the government does not deviate too far from the interests of the majority of the people. Given that a democratically elected government has the potential to become a government that against the will of the people at times. In other words, a lack of balance has the potential to create an uncontrollable force that can do whatever it wants without significant obstacles. Defending the opposition is thus synonymous with defending democracy, given that the goal is for the government to produce better policies and carry out the duties of the state and government, which is consistent with the aspirations and principles of people's sovereignty.

Second, the opposition keeps policy alternatives being expressed. Opposition will allow more policy options or alternative improvements to government policies 


\section{Busman Edyar, Ilda Hayati, Gusti Pangestu The Opposition in The Shar'i Text and The Constitution}

to emerge. This is consistent with the fact that no government is without flaws. Even the best government led by them requires indirect support from opposition groups in order to better capture the people's aspirations and interests. The barrenness of the opposition, then, is a limitation of options for upholding people's aspirations, which, if carried out for a long time, can lead to government decline, as happened in Myanmar under the military junta or Indonesia during the New Order era. In other words, opposition is required in order to develop a more comprehensive policy and minimize errors.

Third, the opposition encourages healthy competition among political and government elites. A government will stagnate, if not decline, if it is not challenged by competent parties capable of demonstrating to the public that there are other policies that make more sense than government policies. The existence of opposition will "awaken" the ruling government to the fact that there are other parties that can offer better policies, which has the potential to "disrupt" the government's positive image in the eyes of the public. As a result, the government requires the opposition as a stimulus to improve performance and maintain its public image. In this situation, a healthy competition between the government and the opposition to improve for the sake of improvement emerged. Consequently, it is clear that the strengthening of the opposition is linked to efforts to enact policies that are in the interests of the people and avoid the emergence of oligarchy. Opposition is more than just an anti-government attitude or a different origin; it is a way of life that provides criticism as well as alternative policies and controls over government administration. As a result of the institutionalization of power, opposition is "rational siding." A healthy opposition is both a part of and a reflection of the existence of a strong democracy.

Once the importance of opposition in the life of the state has been established, even in Indonesia, this opposition should be institutionalized in order to create a democratic political culture and increase the legitimacy of the democratic system. The goal is to fortify representative democracy and formal governance structures so that they become more coherent, complex, autonomous, and adaptable, and thus more capable, effective, valuable, and binding. When a democratic system necessitates the existence of an opposition, institutionalization can be interpreted as acceptance of the opposition's values and norms. Political institutionalization can be viewed in the context of political development as an effort to increase the capacity and differentiation of the political system in terms of its outputs and the 
NEGREI : Academic Journal of Law and Govenance,

Volume 1, Number 2, 2021

extent to which the political system can influence society. At this level, people's acceptance of the values and norms inherent in the democratic system must include not only the presence of a democratically elected government, but also the presence of the opposition as an inseparable part of the democratic system. Political institutionalization, in turn, is an effort to mature democracy, which leads to the strengthening of the government as a policy implementer and the opposition as a balancer and control of power (checks and balances). The government as executor and the opposition as opponents, both have political legitimacy to carry out their respective roles.

The lack of an institutionalized opposition in political life may pose a future threat to the institutionalization of democracy. The failure of political parties with positions in the House of Representatives (DPR) to function in control roles creates opportunities for the growth and development of extra-parliamentary opposition forces. Furthermore, as evidenced by the low level of public political participation, this situation will result in a crisis of legitimacy for both the government and political parties. Building a healthy and effective opposition is far more likely to restore people's trust than sitting in a position of power. According to Confucian government teachings, a country is better off without weapons and food than it is with people's trust.

\section{Opposition in the Shari'a Text}

In general, power, according to Islam, is a trust or a trust that will be held accountable. The Prophet stated in one of his hadiths:

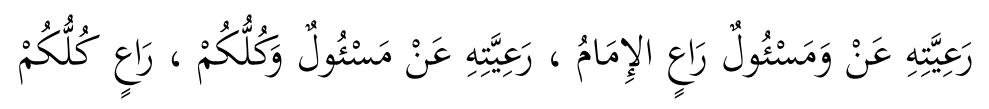

"All of you are shepherds, and every one of you is responsible for his herd. A leader will be beld accountable."

Because power is a mandate, it must be wielded correctly and responsibly. People who do not carry out the mandate are classified as hypocrites, according to the Prophet Muhammad, and one of the characteristics of a hypocrite is that if he is given a mandate, he does not fulfill it (betrays it).

In fact, power in Islam is a two-edged sword; on one hand, it can be used to benefit others more. Because, when compared to those who are not in power, those who are in power have more opportunities to do good with a broader reach. 


\section{Busman Edyar, Ilda Hayati, Gusti Pangestu The Opposition in The Shar'i Text and The Constitution}

Since the one in power has budgetary authority and the authority to order based on the portion of his power. Therefore, that individual can be included in the category of the best human group, as the Prophet Muhammad stated:

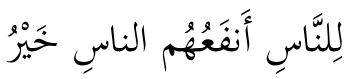

\section{"The best of people are the most beneficial to others."}

Meanwhile, power can also have the opposite meaning, which is that it is used to serve the vested interests of individuals, groups, or families while ignoring the interests of the people (public benefit). Thus, rather than adding to the community's benefits, this group is causing harm to others. This kind of power will undoubtedly have a broader and more massive impact. That is why, when the supreme power of the state was placed on the shoulders of Umar ibn Abdul Aziz, one of the khalifah of the Umayyad dynasty, he cried. He was concerned that he would be unable to uphold this expectation. This is also why Plato (427347) demanded that candidates for state leaders not have families, because he saw family attention as the source of all corruption (abuse of power). They cannot also have private property because having property stimulates the desire to have more wealth. As a result, it continues to foster personal selfishness, rendering the ruler blind to the interests of the country he governs.

Because power has both positive and negative consequences, there must be an effort to remind those who are not in positions of power. The opposition's discourse, which serves as a balancing group or a warning to the authorities, finds its relevance at this level. In general, the command to form a balancing group is included in Allah's terminology of da'wah in Quran surah Ali 'Imran 104:

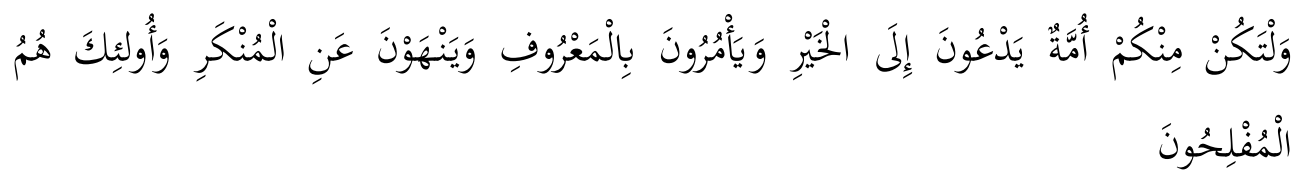

"Let there be a group among you who call 'others" to goodness, encourage what is good, and forbid what is evil-it is they who will be successful.."

On the basis of this verse, the scholars agreed that da'wah (reminder) is obligatory. According to the proposed method, this determination is taken from 
NEGREI : Academic Journal of Law and Govenance,

Volume 1, Number 2, 2021

the waltakun sentence in the form of sighat amr, indicating that the commands amar ma'ruf and nahi munkar in that verse are obligatory (fardu).

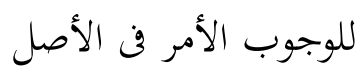

(Basically, amr is required.). In this case, al-Gazaliy introduced, among others, da'wah as an obligation that cannot be negotiable about its obligations, because the verse explains that human happiness is related to the implementation of amr ma'ruf and nahi munkar.

Undeniably, scholars disagree on the meaning of minkum in the verse above. The location of this difference, according to Quraish Shihab, is that there are scholars who understand in a limited sense, so the da'wah command ordered by the verse is not directed at everyone. For those who interpret it in this manner, this verse is for those who contain two types of commands. The first commandment to all Muslims is to form and train a special group tasked with carrying out da'wah for good and ma'ruf, as well as preventing evil. In this case, the first command could be a social institution whose task it is to carry out da'wah and which has special activities to launch da'wah. The second commandment is that the da'wah that is being implemented is for the sake of goodness and not for the sake of evil.

According to interpreters, the word minkum is an explanation (lil bayan), while others say it is a part (littab'iidh), but both can be used in the legal status of da'wah, depending on where this legal position is located. If it is lil bayan, then da'wah is an obligation for every Muslim regardless of ability, but if they are in a littab'idah position or are part of a group tasked with carrying out da'wah, then the two meanings of lil bayan and littab'idah are placement and responsibility. Da'wah is based on Muslims' ability to uphold the truth; it is possible that lil bayan is a Muslim with authority (power).

In this verse, Allah instructs mukmin to invite people to goodness, enjoin good deeds, and forbid evil deeds. And let there be among you a group of people who constantly call to goodness, namely Allah's instructions, to command (do) what is right, namely morals, behavior, and noble values and customs that develop in society which does not contradict religious values and prevents what is munkar, that is considered bad and is denied by common sense. Those who practice these three things have a high standing with Allah, and they are the fortunate ones because they receive salvation in this world and the next. 
Busman Edyar, Ilda Hayati, Gusti Pangestu The Opposition in The Shar'i Text and The Constitution

*This is consistent with the Prophet's hadith:

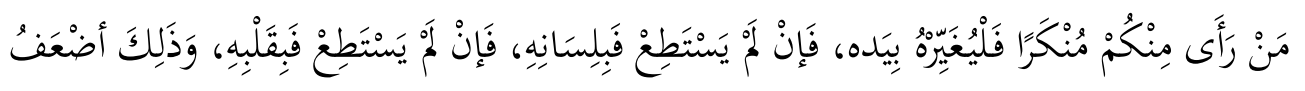

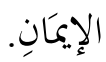

"Whoever amongst you sees an evil, he must change it with his hand; if he is unable to do so, then with his tongue; and if he is unable to do so, then with his heart; and that is the weakest form of Faith."

Because efforts to remind each other are important in the life of society and the state, Allah reminds Muslims who have lost their power of mutual control to join the ranks of those who are truly losers in their lives. Allah says in Quran surah Al Asr:

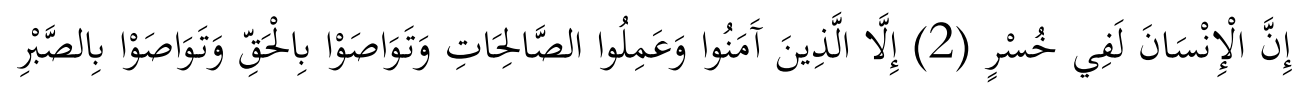

"Indeed, mankind is in loss. Except for those who have believed and done righteous deeds and advised each other to truth and advised each other to patience."

Apart from being in the category of losers, this lack of mutual control creates opportunities for Allah's punishment to fall, as He says in the Quran surah AlMaidah (78-79);

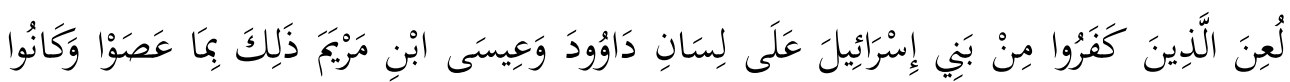

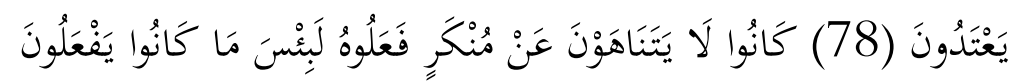

"Cursed were those who disbelieved among the Children of Israel by the tongue of David and of Jesus, the son of Mary. That was because they disobeyed and [habitually] transgressed. They used not to prevent one another from wrongdoing that they did. How wretched was that which they were doing."

This is also something that the Prophet Muhammad reminded us of; 
NEGREI : Academic Journal of Law and Govenance,

Volume 1, Number 2, 2021

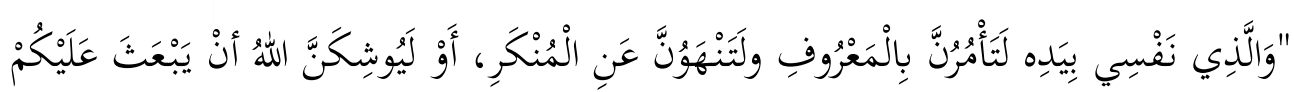

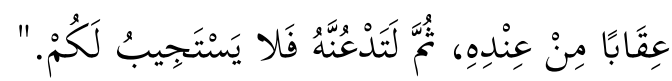

"By the One in Whose Hand is my soul! Either you command good and forbid evil, or Allah will soon send upon you a punishment from Him, then you will call upon Him, but He will not respond to you."

Some of the texts or hadiths mentioned above demonstrate that the role of reminding (as played by the opposition) is essential in Islam. Apart from being carried out individually or in groups, this effort to remind each other can also be carried out in the form of a well-organized institution. According to David Bourchier, "the system of checks and balances in Indonesia's political system is chronically weak, and it is difficult to see any other power except institutional opposition acting as an effective restraint on executive authority."

Even in the past, especially in the interests of the state, the institution was made mandatory to achieve this goal. This is what the ushul rules call it:

$$
\text { ما لا يتم الواجب إلا به فهو واجب }
$$

"It is an obligatory to do what cannot be done without it."

Alternatively:

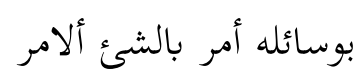

"An order to do something is also an order to fulfill obligations with other people."

In this context, when ordered to perform the obligation of amar makruf nahy munkar, whatever media is required to achieve the order's implementation is mandatory. This includes institutionalizing the opposition in order to make it more organized. Exactly the words of Mustafa Shabri Afandi (Turkish scholar b. $1373 \mathrm{H} / 1954 \mathrm{AD})$ :

$$
\text { الحق بلا نظام يغلبه الباطل بالنظام }
$$

"Falsehood that is well-organized can defeat unorganized truth." 


\section{Busman Edyar, Ilda Hayati, Gusti Pangestu The Opposition in The Shar'i Text and The Constitution}

On that basis, Fami Huwaydi (1996) is not exaggerating when she says that opposition is not only a right, but an obligation. This opposition's obligation is the same as the obligation of amar ma'ruf nahy munkar, which must exist in the Islamic social structure (QS.3: 104). As a result, the opposition can play a role in fostering concrete participation in the political process, encouraging all elements to produce the best for the nation's life. In this framework, the opposition will undoubtedly be the best power partner. Since opposition removes power from the possibility of deviating from universal desires shared by many people. Checks and balances, as Cak Nur stated, are essential in a healthy democracy. As a result, there is a power for monitoring and balancing. As, from a philosophical standpoint, humans cannot always be right. As a result, there must be a method for reminding each other of what is bad and wrong. Next, we value someone's attitude toward their commitment. "I want to implement Pancasila and the 1945 Constitution in a pure manner," for example. In doing so, he is not always correct. As a result, the community must have some kind of mechanism for exchanging ideas without jeopardizing his good faith. In a more sophisticated sense, there is freedom of expression, academic freedom, press freedom, and so on.

The historical journey of the prophets' sending is implicitly a fight against authoritarian, dictatorial forms of power that deny the dignity and worth of human values. Faced with King Namrudz's dictatorship, Prophet Ibrahim fought with King Pharaoh until Prophet Muhammad faced arrogant and antagonistic rulers of the Quraysh tribe with the goal of awakening them to return to hanif values. The opposition's activity was the Prophets' resistance. The prophets stand in opposition to unjust rulers who seek to distance themselves from tauhid values.

\section{Opposition in the Constitution}

As a democratic country, Indonesia incorporates opposition into the fabric of state life. This is because the opposition can play an important role in state administration by controlling the government, testing its policies, pointing out its flaws, and providing alternative solutions to the nation's problems. It's just that in Indonesia, the existence of the opposition is not institutionalized. Aside from not being included in the constitution, the tradition of opposition is not uncommon in the country's politics. Following the fall of the New Order, political parties appear to be more concerned with being part of the government 
NEGREI : Academic Journal of Law and Govenance, Volume 1, Number 2, 2021

than with remaining outside of power. At least one or two political parties choose to operate outside of the lines of power. As a result, the political parties that did not join became a minority group with little clout in opposing the government, which was backed by the majority of political parties. It's no surprise that the country's system of checks and balances is failing. The government, comprised of the major political parties, is very comfortable formulating and enforcing policies without interference from non-government political parties.

After the failure of the parliamentary system that accommodated the opposition system during the Sukarno era (Old Order), Indonesia had practically abandoned this oppositional tradition. The New Order government, which acknowledged the existence of the United Development Party (Partain Persatuan Pembangunan, PPP) and the Indonesian Democratic Party (Partain Demokrasi Indonesia, PDI) in addition to the Party of Functional Groups (Partai Golongan Karya, Golkar), was nothing more than a consolation prize for the victims of the country's democratic life. They will not be allowed to grow and develop, let alone become a formidable opposition force.

The issue is that the opposition is only used to seize power. For example, the opposition was used as a tool to gain leadership positions in the representative body in the DPR of Republic of Indonesia for the 2014-2019 period. As a result, there were clashes and the politics became agitated. The ruling government (read: Jokowi's period) is in the shadow of the DPR-controlled opposition. Political instability is also exacerbated by the ruling government's retaliation in the form of marginalization of opposition parties. For example, as in the New Order era, creating a dualism in party leadership and limiting party access to economic units, the media, and others. Even the law enforcement is frequently exerted against members of the opposition as a form of warning, as are political hostages held hostage to support the government. This also occurred and was practiced by the ruling government during the Reformation Era. Furthermore, the issue of political party funding resources is frequently used as an excuse for political parties to be hesitant to remain in opposition. As a result of these circumstances, the opposition shifted its position and backed the government. The president, who was initially supported by a minority of votes in the DPR, eventually became the majority's dominant supporter. The opposition in the DPR has weakened to the point of being non-existent. 


\section{Busman Edyar, Ilda Hayati, Gusti Pangestu The Opposition in The Shar'i Text and The Constitution}

Undeniably, because Indonesia follows a presidential system, the opposition cannot be implemented as it would in a parliamentary system. The role model of the opposition as practiced in the United States, on the other hand, appears to be applicable where the relationship between the opposition party and the government is not adversarial, but can cooperate or negotiate for the greater good. The role model of the opposition that is carried out is not one of "resistance" with the goal of bringing down the government through a vote of no confidence, as is often the case in parliamentary governments, but one of checks and balances with the goal of negotiating policies in the national interest. Indeed, negotiations between the government and the opposition do not always result in a government victory. For example, in the case of President Obama's administration in the United States, the opposition could not file a vote of no confidence as in the parliamentary system. In this case, the President and the US Congress cannot overthrow each other, which can only be accomplished by vetoing the policies proposed by both institutions.

The Justice Party (Partai Keadilan, PK. Then Prosperous Justice Party (PKS)) played the role of the opposition outside of power during the reformation period, specifically during the government led by Megawati Sukarnoputri (2001-2004). This continued during the Susilo Bambang Yudhoyono (SBY) administration (2004-2014), even though the the Indonesian Democratic Party of Struggle (Partai Demokrasi Indonesia Perjuangan PDI-P) was no longer in power and had declared itself an opposition party. Then, during the Jokowi administration (2014-2024), several political parties, including the Prosperous Justice Party (Partai Keadilan Sejahtera, PKS) and the Democratic Party (Partai Demokrat), chose to remain on the sidelines.

The above-mentioned opposition role of political parties in the DPR is indeed in accordance with the constitution. This is because, in addition to legislative and budgetary functions, the DPR is responsible for overseeing the implementation of laws and budgets. The DPR then has the authority to summon state officials to a meeting with the DPR in order to carry out its duties. If they refuse to, they can call the cops. Government administrators may receive a recommendation from the DPR; if this recommendation is ignored, it is very likely that it will be followed by the use of the right of interpellation (requesting information from the Government regarding important and strategic policies that have broad implications for the life of society, nation, and state); the right to express opinions 
NEGREI : Academic Journal of Law and Govenance,

Volume 1, Number 2, 2021

(to conduct an investigation into the implementation of a law and/or Government policy relating to significant, strategic, and broad impacts on the life of society, nation, and state that are suspected to be contrary to the laws and regulations); and the right to ask related questions a. government policies or regarding extraordinary events that occur in the country or internationally; b. follow-up to the implementation of the right to have an interpellation c. allegations that the President and/or Vice President have broken the law through treason against the state, corruption, bribery, other serious crimes, or disgraceful acts, and/or the President and/or Vice President no longer meet the requirements for President and/or Vice President. After going through the Constitutional Court's examination process, the DPR even proposed dismissing the People's Consultative Assembly (MPR) when the president committed human rights violations, criminal acts, and violated state policy, bribery.

Accordingly, the figure of a state administrator cannot simply develop or implement policy on its own. It must pay close attention to the DPR institution, which will serve as a balancing partner in carrying out its responsibilities. State administrators must involve the DPR in policymaking in addition to being supervised by the DPR. According to Article 71 of Law No. 17 of 2014 concerning the People's Consultative Assembly, the People's Representative Council, the Regional Representatives Council, and the Regional People's Representative Council, the DPR has the authority to: a. establish laws that are discussed with the President for mutual approval, b. approve or disapprove government regulations in lieu of laws proposed by the President to become law; c. debate draft laws proposed by the President or DPR; d. debate the Regional Representatives Council's (DPD) draft law on regional autonomy, central and regional relations, the formation, expansion, and amalgamation of regions, management of natural resources and other economic resources, and the balance of central and regional finances. e. discuss with the President, taking into account the DPD's recommendations, and approve the President's draft law on the State Budget; discuss and follow up on the results of supervision submitted by the DPD on the implementation of laws on regional autonomy, formation, expansion, and merger of regions, central and regional relations, management of natural resources and other economic resources, implementation of State Budget (APBN), taxes, education, and reliabilities; give approval to the President to declare war and make peace with other countries; give approval to certain international agreements that have broad and fundamental implications for 


\section{Busman Edyar, Ilda Hayati, Gusti Pangestu The Opposition in The Shar'i Text and The Constitution}

people's lives related to the burden of state finances and/or require amendments or the formation of laws; give consideration to the President in granting amnesty and abolition; consider the President when appointing ambassadors and accepting the placement of ambassadors from other countries; k. elect members of the Audit Board of the Republic of Indonesia (BPK) while keeping the DPD in mind; 1. recommend to the President the appointment and dismissal of members of the Judicial Commission; $\mathrm{m}$. recommend to the President candidates for Supreme Court justices proposed by the Judicial Commission for appointment as Supreme Court justices; and n. elect three constitutional judges and present them to the President for appointment by presidential decree.

Thus, the DPR's vital role in controlling the state can be seen, even though in practice, the DPR's maximum control function as opposed to the opposition was only seen during the old order government (in 1955-1959 to be precise). However, the ups and downs of the cabinet at the time, combined with ongoing state ideological debates, forced President Sukarno to suppress the DPR with his decree on 5 July 1959. As a result, the DPR has been under Sukarno's control since then, until his demission in 1966. Not much different during the New Order era. The existence of the PPP and the PDI, both of which exist outside of the Golkar-supported government system, is merely lip service. This is due to the Suharto regime's tight control over the existence of DPR members in general. Members of the DPR from any political party who are vocal in their opinions risk being recalled by the party to which they belong. Only during the Reformation period did things begin to change. DPR control appears to be strong and dominant. Even President Abdurrahman Wahid was deposed by the DPR in a special session of the MPR, which included the majority of DPR members. The factions in the DPR tend to be closer to power on the next trip. Except during the SBY era, the PDI-P declared itself an opposition party with little clout in policymaking because it was a minority force in the DPR. Finally, only the PKS and the Democratic Party were out of power during Joko Widodo's reign (20142024). Other political parties join the government party.

The role of the opposition party is actually beneficial for efforts to uncover a number of issues related to government policies that were left unresolved during the New Order era. This is consistent with Leslie Lipson's $(1964,247)$ assertion that "in some democracies-both those that adhere to the majority and consensus models, even though mixed-opposition parties can unmask what the ruling party 
NEGREI : Academic Journal of Law and Govenance,

Volume 1, Number 2, 2021

does when carrying out its actions." unjust treatment. To be able to expose injustice if it exists, there must be an opposition." With the opposition in place, the government will be more cautious in making decisions because the possibility of being questioned by the opposition increases. This means that the presence of an opposition party can energize the DPR's role as an institution tasked with controlling government power.

Because the existence of the opposition is critical to the functioning of the state, it is necessary to mainstream it in society. Political education about democratic development and the critical role of the opposition, particularly in relation to citizens' rights and obligations to participate in politics (including criticizing authorities), should be a priority for these formal and non-formal institutions. Institutions such as universities and political awareness institutions, both public and non-governmental, play an important role in this context. Furthermore, the media can play a role in it by, for example, providing support and appreciation for the opposition's power. Critical groups opposing the government must also be given equal space and encouragement in the media. It must be admitted that many mass media outlets still take sides, either because of ideological similarities or interests, or because of other factors that are symbiotic mutualism or even collusive. Whatever the cause, as long as this remains a symptom, efforts to raise and build the opposition will face significant challenges. As a result, there should be an impetus from both within (self-criticism) and without for the mass media to recognize their critical role as the fourth pillar of democracy. In that position, the media is not only dedicated to "what is important is the same" or "what is important is different" with the authorities, but can also participate in controlling the course of government by prioritizing objective rationality and a commitment to fight for the people's aspirations or sovereignty to the fullest extent possible. Furthermore, in the midst of society, it is time to cultivate a political maturity movement that is willing to cultivate habituation and respect for differences, tolerance, and responsible attitudes or differences, or the existence of alternative groups. Political differences are not a sign of disloyalty, but rather an effort to strengthen improvements through a variety of alternative solutions. The presence of the appropriate understanding will also cause the community to automatically provide more expressive and meaningful support for government or political elite actions or policies that are deemed detrimental to their interests. 
Busman Edyar, Ilda Hayati, Gusti Pangestu The Opposition in The Shar'i Text and The Constitution

\section{Conclusion}

The role of opposition in the administration of a democratic state is inextricably linked. It plays a strategic role in ensuring that good governance is implemented. In absolute terms, the state should not be left alone to formulate and implement a policy that it has planned. It is too naive to rely solely on state administrators without any oversight from the opposition.

This control function in Islam can be traced back to the Qur'an or hadith that calls for a balancing group. The absence of this balancing group can not only harm a nation, but it can also result in disaster for the nation where the state is easily abused or misused for the benefit of individuals or groups.

The Indonesian constitution does not affirm the existence of this opposition institution, but the DPR's role as a people's representative can carry out the opposition's role. The law guarantees and grants the DPR several special rights to carry out its function as a control, supervisor, or balancer in state administration. 
NEGREI : Academic Journal of Law and Govenance,

Volume 1, Number 2, 2021

\section{Bibliography}

Djaja, Ermansjah, 2010, Meredesain Pengadilan Tindak Pidana Korupsi, Jakarta: Sinar Grafika

Echols, John M dan Hasan Shadily, Kamus Inggris-Indonesia, (Jakarta : Gramedia Pustaka Utama, 1993), Cet. XIX

Filiang, Yasraf Amir, Pengantar dalam Jika Rakyat Berkuasa ; Upaya Membangun Masyarakat Madani dalam Kultur Feodal, (Jakarta : Pustaka Hidayah, 1999), Cet. I

Al-Ja'fi, Muhammad ibn Ismail Abu Abdullah al-Bukhari, Sahih Bukhari, (Beirut : Dar Ibn Kasir, 1407/1987), Cet. III, Juz. I

Kleden, Ignas, Oposisi dalam Politik Indonesia, dalam Jika Rakyat Berkuasa ; Upaya Membangun Masyarakat Madani dalam Kultur Feodal, (Jakarta : Pustaka Hidayah, 1999), Cet. I

Al-Lathif, Abdurrahman ibn Shaleh Ibn, Qawa'id wa Dhawabith Al-Fiqhiyah, (Madinah : Imadah al-Bahs al-Ilmiy bi al-Jami'ah al-Islamiyah, 1423/2003), Juz. I

Madjid, Nurcholish, Dialog Keterbukaan : Artikulasi Nilai Islam Dalam Wacana Sosial Politik Kontemporer (Bandung: Ellunar Publisher, 2018), Cet. I

Al-Nisabury, Abu Husein Muslim ibn al-Hajaj ibn Muslim al-Qusyairy, Sahih Muslim, (Beirut : Dar al-Jiil Beirut/Dar al-Ufuq al-Jadidah, Tt), Juz. VI

Suseno, Franz Magnis, Machiavelli : Guru Benar atau Guru Konyol dalam Jika Rakyat Berkuasa ; Upaya Membangun Masyarakat Madani dalam Kultur Feodal, (Jakarta : Pustaka Hidayah, 1999), Cet. I

Al-Syaibany Abu Abdullah Ahmad Ibn Muhammad Ibn Hanbal ibn Hilal ibn Asad, Musnad Ahmad ibn Hanbal, (Beirut: Alim al-Kutub, 1419/1998), Juz. V

Al-Thabrani, Abu al-Qasim Sulayman ibn Ahmad, Mu'jam al-Ausath, (Kairo : Dar al-Haramain, 1415), Juz. VI

Assagaf, Ja'far, Keotentikan Ungkapan Imam Ali Kw dalam Asosiasi Ilmu Hadis Indonesia, https://www.asilha.com/2020/05/07 diunduh tanggal 4 Desember 2021

Atmojo, Tuswoyo, Peran Partai Oposisi di Parlemen Pasca Pemilu Presiden 2014, Jurnal Politik, Vol. 1, No. 2, Februari 2016

Eldison, Reformasi Birokrasi Menciptakan Aparatur Yang Baik, dalam sumbar.kemenag.go.id, diakses tanggal 15 November 2021 
Busman Edyar, Ilda Hayati, Gusti Pangestu The Opposition in The Shar'i Text and The Constitution

Lotulung, Paulus E, dalam Jemmy Jefry Pietersz, Prinsip Good Governance dalam Penyalahgunaan Wewenang, dalam Jurnal SASI, Volume 23 Nomor 2, Juli - Desember 2017

Maryam, Neneng Siti, Mewujudkan Good Governance Melalui Pelayanan Publik, dalam Jurnal Ilmu Politik dan Komunikasi Volume VI No. 1/Juni 2016

Noor, Firman, Oposisi dalam Kehidupan Demokrasi, dalam Jurnal Masyarakat Indonesia, Vol. 42 (1), Juni 2016

Radjab, Syamsuddin, Konvergensi Islam-Negara dalam Politik Indonesia dan Urgensi Partai Oposisi, Makalah disampaikan dalam Pelatihan Mujahid Politik Partai Bulan Bintang (PBB) yang dilaksanakan pada Sabtu, 7 April 2018 oleh DPP PBB di Hotel New Ayunda Puncak, Megamendung, Bogor.

Suryadi, Suhardi, Membangun Tradisi Oposisi, http://ditpolkom.bappenas.go.id/ diakses tgl 19 November 2021

Syafriani, Desi, Hukum Dakwah dalam Quran dan Hadis, Jurnal Fuaduna: Jurnal Kajian Keagamaan dan Kemasyarakatan Vol. 1, No. 1, Januari- Juni 2017

Syamsuri, Ontologi Dakwah (Upaya Membangun Keilmuan Dakwah), Jurnal Hunafa Vol. 3 No. 2, Juni 2006

Tuswoyo, Pelembagaan Oposisi dalam Sistem Presidensial: Studi Tentang Oposisi PDIP di DPR, dalam Jurnal Social Justice, JISPO, VOL. 1 Edisi: Januari-Juni Tahun 2013

Peraturan Pemerintah Nomor 101 Tahun 2000

Susanto, Mei, Pelembagaan Oposisi dalam Badan Perwakilan Rakyat Indonesia, dalam https://meisusanto.com

Kamus Besar Bahasa Indonesia, kbbi.web.id/oposisi

Tafsir Ringkas Kementerian Agama Republik Indonesia dalam https://quranhadits.com

UU No 17 Tahun 2014 tentang Majelis Permusyawaratan Rakyat, Dewan Perwakilan Rakyat, Dewan Perwakilan Daerah, dan Dewan Perwakilan Rakyat Daerah

Undang-Undang Dasar 1945 Amandemen Ketiga. 
NEGREI : Academic Journal of Law and Govenance, Volume 1, Number 2, 2021 